\title{
FIM DE LINHA
}

Um poeta antigo e ático, desterrado da Grécia amada ardentemente, escreveu um dia de densas nuvens baixas (baixas no espírito, pois corriam altas esboçando no azul o seu vôo alvo), esse poeta antigo escreveu um dia que a todo mundo chega a hora decisiva de dizer "sim" ou "não" para fazer da vida uma linha forte em geometria exata.

Um professor que leu esse poeta antigo e esse poema escrito sobre o "sim" ou "não", comentário de Dante sobre outro mestre; esse professor, quando novo e apesar de cético, que disse um dia "sim" ao ensino e ao ensinar, pondo no ensino a sina de formar, que disse, então, um "sim" amoroso e incontido, "sim" que o laçou e aos poucos o foi gastando entre o agora, o talvez, o amanhã e o quando; esse professor, que se foi gastando com o afã de formar ou ensinar aos outros, se empurra para o mais distante exílio, agudo e fatal, violento e definido; esse professor agora se pergunta: "Como continuar formando generoso, se me deformei de mim para formar?"

É outro, assim, o momento decisivo, em que deve dizer "sim" ou dizer "não". Nesta outra hora, porém, cansado dos sentidos, e cegando-se à luz intensa da razão, não vê mais os jovens vagos e indecisos.

Diz então um "basta", e este "não" vai perseguir a este justo altivo pelo resto da vida sem perdão.

Antônio Manoel dos Santos Silva ${ }^{1}$

\footnotetext{
${ }^{1}$ Professor de Teoria da Literatura e Literatura Brasileira. Reitor da Universidade Estadual Paulista /UNESP
} 

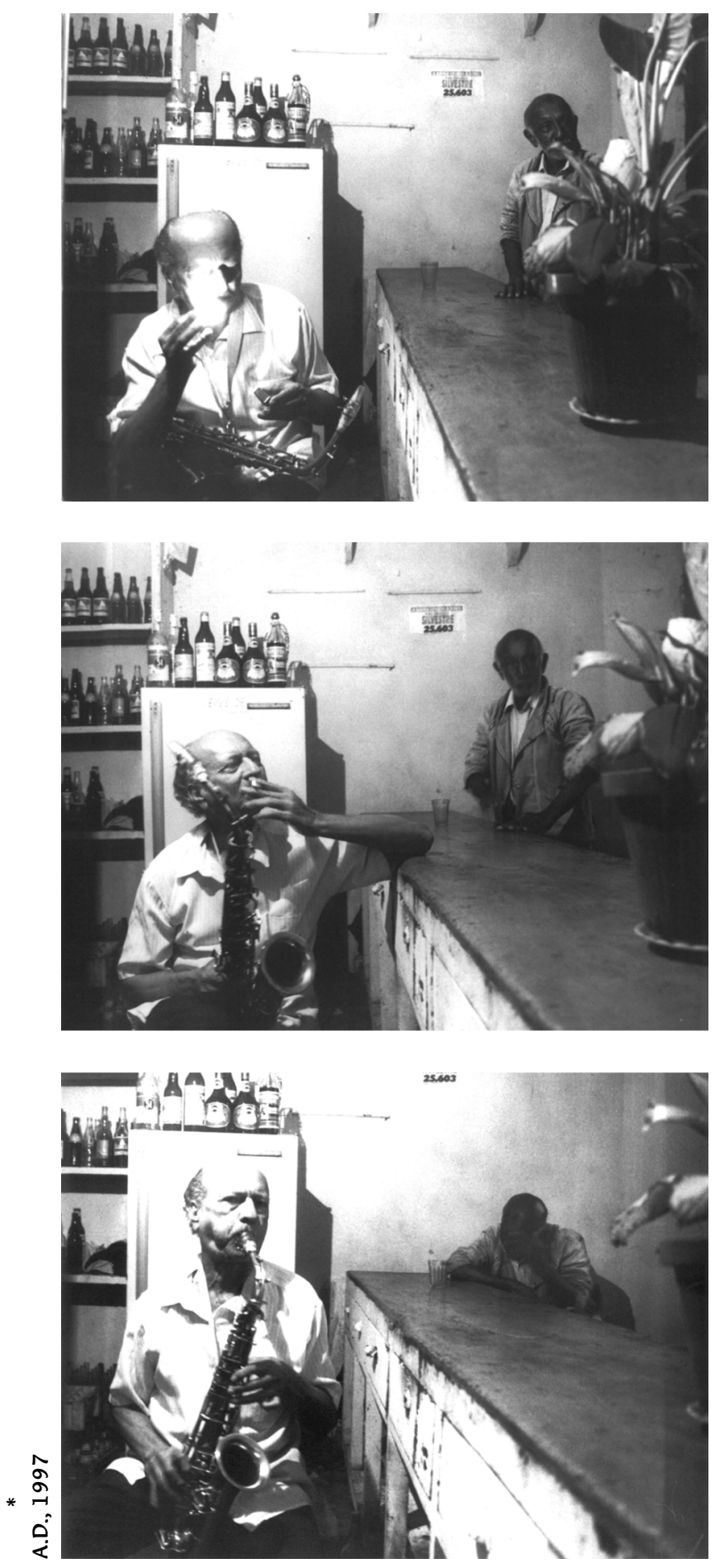

* Alexandre Dimitrov é estudante de engenharia mecânica na Escola Federal de Engenharia de Itajubá. Entre números e cálculos, lógica e razão, procura na fotografia "os sentidos em qualquer dos sentidos". 